\title{
Olgularla Hematolojik ve Onkolojik Aciller
}

\author{
Hematological and Oncological Emergencies with Cases
}

\section{Can ACIPAYAM ${ }^{1}$, Tuğba KANDEMİR GÜLMEZ ${ }^{2}$, Muhammed PARLAR ${ }^{2}$, Osman Nuri ÖZEN $^{2}$, Salim EKİCI' ${ }^{2}$, Mehmet ÖRENLER ${ }^{2}$}

${ }^{1}$ Doç. Dr. Kahramanmaraş Sütçü İmam Üniversitesi Tip Fakültesi, Çocuk Sağlığı ve Hastalıkları Anabilim Dalı, KAHRAMANMARAŞ
${ }^{2}$ Ar. Gör. Dr. Kahramanmaraş Sütçü İmam Üniversitesi Tip Fakültesi, Çocuk Sağlığı ve Hastalıkları Anabilim Dalı, KAHRAMANMARAŞ

\section{Öz}

Hematolojik ve onkolojik acil durumlar, tüm dünyada acil servislere en çok başvuru sebeplerinden biridir. Bazı hastalar önceden bir tanıya sahip olurken, diğerleri hematolojik onkolojik acil bir durum ile ilk defa acile başvurup sonrasında tanılarını alabilir. Bu yazımızda anemi, orak hücre hastalığı, G6PD enzim eksikliği, anormal uterin kanama, otoimmun hemolitik anemi, von Willebrand Hastalı̆̆ ve immün trombositopeni gibi hematolojik hastalıklar ile nötropenik ateş, tümör lizis sendromu ve vena kava süperior sendromu gibi klasik onkolojik acil durumları içeren geniş bir yelpazeye yayılan konuları hazırladık. Burada olgularla hematolojik ve onkolojik acil olguları sunacağız.

Anahtar Kelimeler: Orak hücre hastalı̆̆ı, nötropenik ateş, tümör lizis sendromu, vena kava süperior sendromu

\section{Abstract}

Hematologic and oncologic emergencies are among the most common cases of administration to the emergency services worldwide. While some patients have a previous diagnosis; others may apply for a hematologic oncologic emergency and then receive their initial diagnosis. In this article, we prepared a series of topics ranging from a series of hematological diseases consisting of anemia, sickle cell disease, G6PD enzyme deficiency, abnormal uterine bleeding, autoimmune hemolytic anemia, von Willebrand's disease and immun trombocytopenia, as well as classical oncologic emergencies such as neutropenic fever, tumor lysis syndrome and vena cava superior syndrome. Here, we present hematologic and oncologic emergency cases.

Key Words: Sickle cell disease, neutropenic fever, tumor lysis syndrome, vena cava superior syndrome

\section{GÍRIŞ}

Hematoloji ve onkoloji hastalarında karşılaştığımız aciller direkt olarak altta yatan hastalıktan olabileceği gibi uygulanan tedaviden dolayı da olabilir. Hastaların ilk tanı anında karşılattığımız acil durumlar hastanın sağ kalımını etkilemesi nedeniyle önemlidir (1). Karşılaşabileceğimiz bu acil durumları kliniğimizde takip ettiğimiz hastalarımızda olgularla farklı örneklerini görmekteyiz.

\section{OLGU SUNUMLARI}

OLGU 1. 3,5 yaşında kız hasta sandalyeden düşme sonrasında çekilen tomografide intrakranial kanama olması üzerine hasta tarafımıza sevk edildi. Hastanın fizik muayenede uykuya meyilli, şuur açık olarak değerlendirildi. Çekilen beyin tomografisinde frontal sefal hematom, serebellumda, supratentorial alanda ve intraserebral kanama saptandı (Resim 1). Lökosit sayısı (WBC): 14080/mm3, Hemoglobin (Hb): 8,1 g/dL, Hematokrit (Hct): \% 25,7, ortalama eritrosit hemoglobini (MCV): $68 \mathrm{fL}$, trombosit sayisı (Plt): $550000 / \mathrm{mm} 3$, Protrombin zamanı (PT): 15,8 sn, INR: 1,3 ve aktivite parsiyel tromboplastin zamanı (aPTT): 49 sn olarak bulundu. von Willebrand antijeni (vWf) \% 10, Faktör VIII düzeyi \% 0,9 olan hastanın suboksipital epidural ve intraserebral hematom boşaltıldı. Hastaya postoperatif Faktör VIII/vWf konsantresi uygulandı ve hasta sorunsuz taburcu edildi.

OLGU 2. 4 aylık erkek hasta vücudunda morarma

$\begin{array}{ll}\text { İletişim: } & \begin{array}{l}\text { Doç. Dr. Can ACIPAYAM, KSÜ Tip Fakültesi Çocuk } \\ \text { Sağlığı ve Hastalıkları AD, Kahramanmaraş }\end{array} \\ \text { DOI: } & \mathbf{1 0 . 1 7 5 1 7 / k s u t f d . 4 2 7 9 7 5}\end{array}$
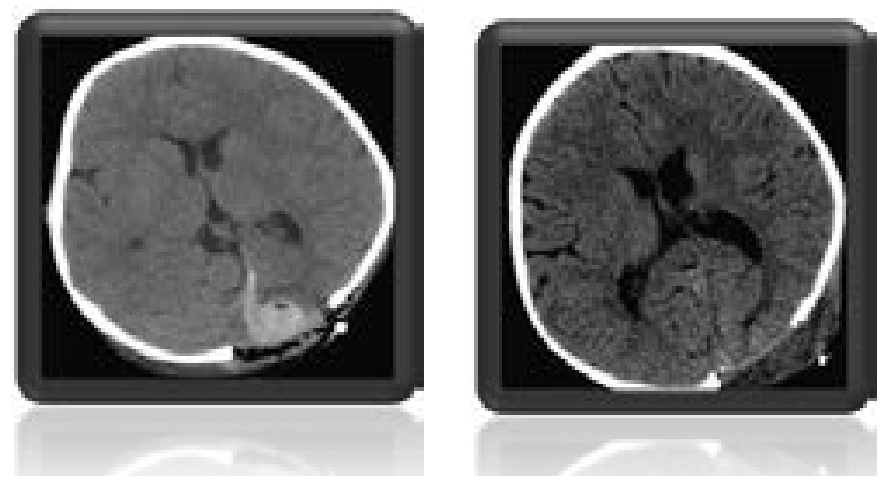

Resim 1. Hastanın kranial tomografisi görüntüsü.

nedeniyle doktora başvurusunda bakılan tetkiklerinde Plt: $24000 / \mathrm{mm} 3$ olması nedeniyle dış merkezde immun trombositopeni olarak değerlendirilip hastaya 1 kez IVIG verilmesi sonrası Plt yükselmemesi üzerine tarafımıza yönlendirildi. Hastanın fizik incelemede vücut 1sısı: 36,9 ${ }^{0} \mathrm{C}$, solunum: $26 / \mathrm{dk}$, nabiz: $150 / \mathrm{dk}$, tansiyon arteriyel: $80 / 50 \mathrm{~mm} / \mathrm{Hg}$ idi. Vücudunda yaygın ekimoz ve sağ el parmaklarda konjenital parmak anomalisi, sağ elde iki adet başparmak iki adet tırnak mevcuttu. PT: 13,2sn, aPTT: 24,3sn, INR: 1,1, WBC: 9530/mm3, MNS (mutlak nötrofil sayıs1): 1280/mm3 Hb: 6,6 g/ dL, Hct: 21,9 MCV: 78 fL, Plt: $2000 / \mathrm{mm} 3$ olan hastanın yapilan kranial tomografide sağ ventrikül posterior hornunda minimal hiperdens alan saptand 1 (Resim 2). Hastaya 2 kez trombosit süspansiyonu ve $1 \mathrm{kez}$ eritrosit süspansiyonu verilerek

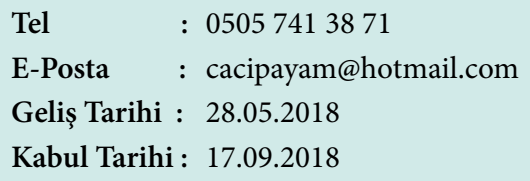


kemik iliği incelemesi yapıldı. İmmun trombositopeni ile uyumlu olarak değerlendirildi. Hastaya IVIG ve steroid tedavileri verildi.

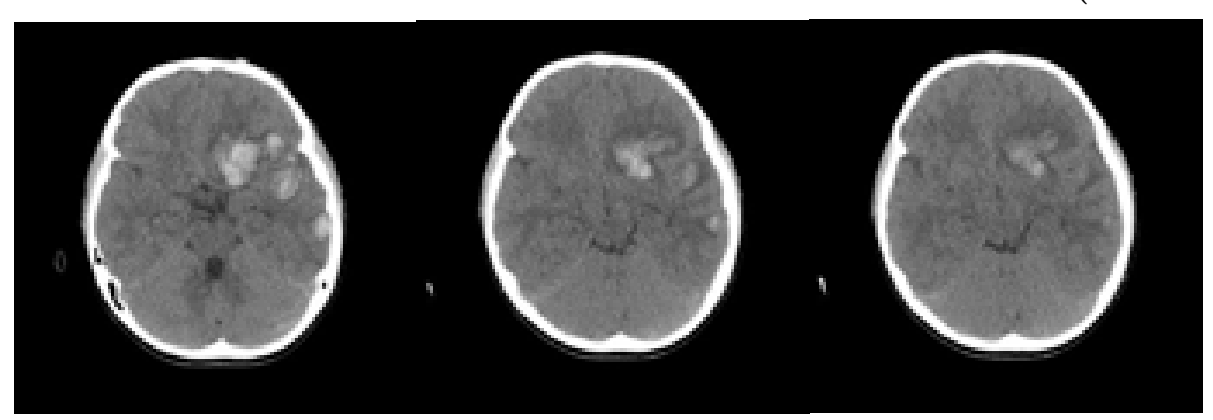

Resim 2. Hastanın kranial tomografisi görüntüsü.

OLGU 3. Daha önceden bilinen hastalık öyküsü olmayan yabancı uyruklu 3 yaşında erkek hasta kanlı idrar yapma solukluk halsizlik şikâyetleriyle başvurdu (Resim 3). Üç gün önce bakla yeme öyküsü olan hastanın gözlerinde sararmalar başlamış. Daha sonra sararması artan ve bütün vücuduna yayılan soluklaşmaya başlayan ve uyku hali olan hasta dış merkezde bakılan tahlillerinde Hb: 6,7 g/dL, Hct: \% 21, total bilirubin:11,2 mg/dL olarak gelmesi üzerine anemi ön tanısıyla tarafımıza sevk edildi. Özgeçmişinde yeni doğan döneminde sarılık öyküsü olan hastanın fizik muayenede sklera soluk, ikterik ve cilt sarı soluk olarak gözlendi. Hepatosplenomegali palpe edilmedi. WBC: 29730/mm3, Hb: 5,8 g/dL, Hct: \% 17,3, MCV: 86,1fL, Plt: $347000 / \mathrm{mm} 3$, retikülosit \% 12, LDH: $725 \mathrm{U} / \mathrm{L}$, direkt bilirubin: $0,72 \mathrm{mg} / \mathrm{dL}$, total bilirubin: 14,4mg/dL, MCV: 86,1fL ve G6PDH: $2,21 \mathrm{U} / \mathrm{g}$ olan hastaya G6PD enzim eksikliğine bağlı hemolitik anemi tanisı konuldu.
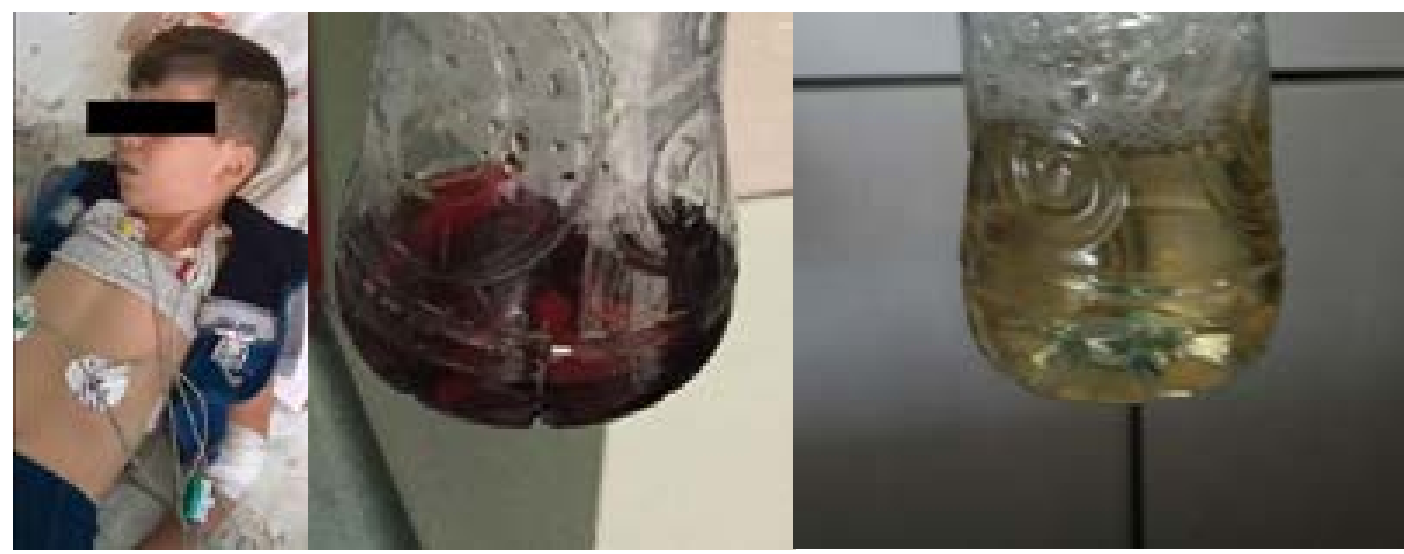

Resim 3. Hastanın ve idrarının görüntüsü.

OLGU 4. Daha önceden bilinen hastalık öyküsü olmayan 2 yaşında erkek hasta 2 gündür sararma solukluk halsizlik şikâyetleriyle acile başvurdu. $\mathrm{Hb}: 5,3 \mathrm{~g} / \mathrm{dL}$, total bilirubin: $5,84 \mathrm{mg} / \mathrm{dL}$, direkt bilirubin: $0,91 \mathrm{mg} / \mathrm{dL}$ olan hasta tarafımıza sevk edildi. Fizik muayenede cilt soluk, mukozalar soluk, sklera ikterik, organomegalisi olmayan hastanın bakılan laboratuvar bulgularında: $\mathrm{Hb}: 4,3 \mathrm{~g} / \mathrm{dL}$, Hct: \% 8,6, MCV: 114fL, Plt: 239000/mm3, retikülosit \% 9, total bilirubin: $5.01 \mathrm{mg} / \mathrm{dL}$, direkt bilirubin: $0,77 \mathrm{mg} /$ dL, direkt Coombs: 4+pozitif, $\mathrm{Hb}$ elektroforezi normal olarak gözlendi. Hastanın diğer tetkikleri normal olarak değerlendirilerek otoimmun hemolitik anemi tanısıyla tedavi başlandi.

OLGU 5. Daha önceden bilinen hemoglobin D tanısı (Resim 4) olan 16 yaşında kız hasta rutin kontrollerde ara sıra karın ağrısı şikâyeti olduğunu söylemesi üzerine hasta karın ağrısına yönelik değerlendirildi. Aile öyküsünde anne-baba 1. derece akraba olan ve ailede amcalarında malignite öyküsü (kolon kanseri) olan hastanın fizik muayenesi normal olarak değerlendirildi. Laboratuvar değerleri: WBC: $8700 / \mathrm{mm} 3, \mathrm{Hb}$ : $8,5 \mathrm{gr} / \mathrm{dL}$, Hct: \% 25,6, MCV: 57 fL, RDW: \% 19,7, Plt: 258000/mm3 ve yapilan batın USG de bilateral overler ayırt edilememekle birlikte, sağ adneksiyel lojda $36 \times 42 \mathrm{~mm}$, sol adneksiyel lojda $42 \times 35 \mathrm{~mm}$ boyutlarında ölçülen solid kitle izlendi. MR görüntülemesinde de sol over lojunda yaklaşık olarak $65 \mathrm{~mm}$ çapında kistik kitle izlendi. Komşuluklarında yaklaşık olarak $5 \mathrm{~cm}$ ve 3,5 $\mathrm{cm}$ boyutlarında, intravenöz kontrast madde sonrasında heterojen, opaklaşan yumuşak doku kitleleri izlendi. AFP: 1,3 IU/mL, beta HCG: <1 U/L, CA-19,9: 29,3 U/ $\mathrm{mL}, \mathrm{CA}-125: 178$ (0-35) U/mL, GGK: pozitif olan hasta biyopsi sonucunda müsinoz kist adenokarsinoma tanısı ald1.

OLGU 6. 12 yaşında kız hasta 4 gündür sağ dizinde ağr1 şişlik şikâyeti ile başvurdu. Hastanın fizik muayenesinde kilo $31 \mathrm{~kg}(<3 \mathrm{p})$, boy $149 \mathrm{~cm}(25-50 \mathrm{p})$, sklera subikterik, 2/6 üfürüm ve sağ dizde artrit saptandı. Hastanın tetkiklerinde indirekt bilirubin: $2,57 \mathrm{mg} / \mathrm{dL}$, direkt bilirubin: 0,54mg/dL, LDH: $658 \mathrm{U} / \mathrm{L}$, retikülosit: $\%$ 9.04, ferritin: 122 olan hastaya periferik yayma yapıldı. Periferik yaymada anizositoz, p o i k i l o s i o z, target hücreleri, gözyaşı hücreleri (hemoglobinopati?) ve oraklaşmış hücreler (orak hücreli anemi?), yer yer sferosit görüldü (Resim 5). Orak hücreli anemi bulgulari saptanması üzerine hastaya hemoglobin elektroforezi yapıldı. HbF: \% 9,5 HbA0: \% 7,2 HbA2: \% 2,9 ve $\mathrm{HbS}$ : \% 80,4 görüldü. Batın USG incelemesinde dalak sonografik olarak değerlendirilemedi. Hastanın aile taramasında; anne ve baba orak hücreli anemi taşıyıcısı ( $\mathrm{HbS} \%$ 34,2 ve $\mathrm{HbS} \%$ 33,3), 14 yaşındaki ağabeyi ile 6 yaşındaki kız kardeşi homozigot orak hücre anemi hastası (HbS \%77,4ve HbS \%73), 3 kardeşi de orak hücreli anemi taşıyıcısı olarak saptandı.

OLGU 7. 13 yaşında kız hasta ilk menstruasyon kanamasından itibaren yaklaşık 9 aydır devamlı fazla miktarda kanamaları olması ve buna bağlı 2 defa 

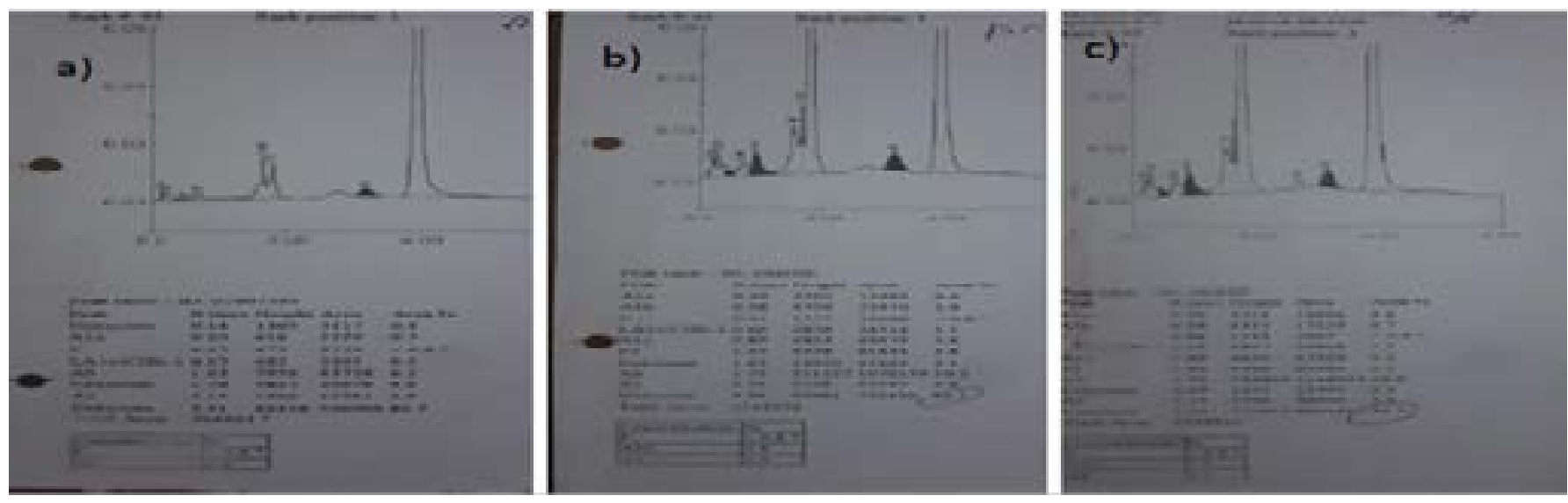

Resim 4. Sırasıyla hastanın, anne ve babasının hemoglobin elektroforez sonuçları.

eritrosit tranfüzyon yapılma öyküsü, solukluk ve halsizlik şikâyetleriyle tarafımıza başvurdu. Hastanın MR görüntülemesinde uterusta asimetrik görünümde bikornuat uterin varyasyon izlendi (parsiyel?). Bu düzeyde tedavi başlandi.

OLGU 8. 9 yaşında erkek hasta 1 haftadır karın ağrısı ve kusma olması nedeniyle başvurdu. Yapılan muayenede genel durum orta-kötü, bilinç açık, göz küresi

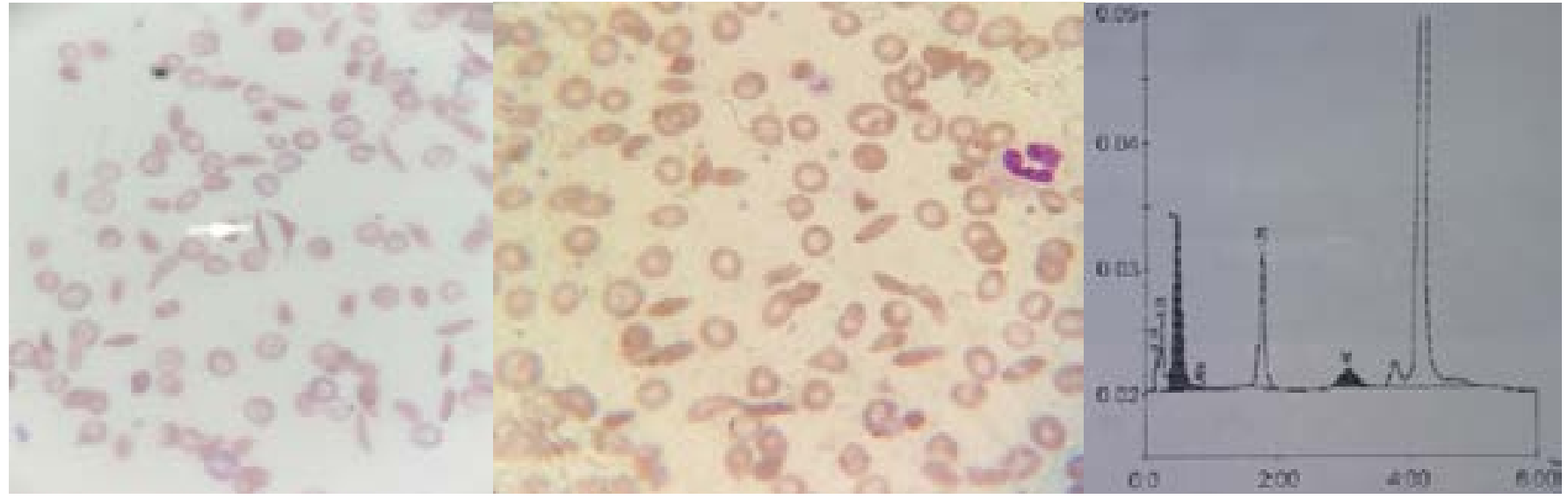

Resim 5. Hastanın periferik yayma ve hemoglobin elektroforezi görüntüsü.

endometriyal kavite ince çizgi şeklinde izlenmekle birlikte distalde serviks ve vajinal kafı dolduran boyutları aksiyel planda $6.5 \times 6 \mathrm{~cm}$ boyutlara ulaşan heterojen sinyalli kontrastlanan lobüle konturlu kitlesel lezyon izlendi (Resim 6). Lezyon inferiorda vajinal duvar ile devamlılık göstermekle birlikte proksimalde servikal orjini net olarak dışlanamayan hasta opere edilerek 10 x $15 \mathrm{~cm}$ boyutlarında kitle çıarıldı. Patolojik olarak alveolar rabdomyosarkom olarak değerlendirilen hastaya

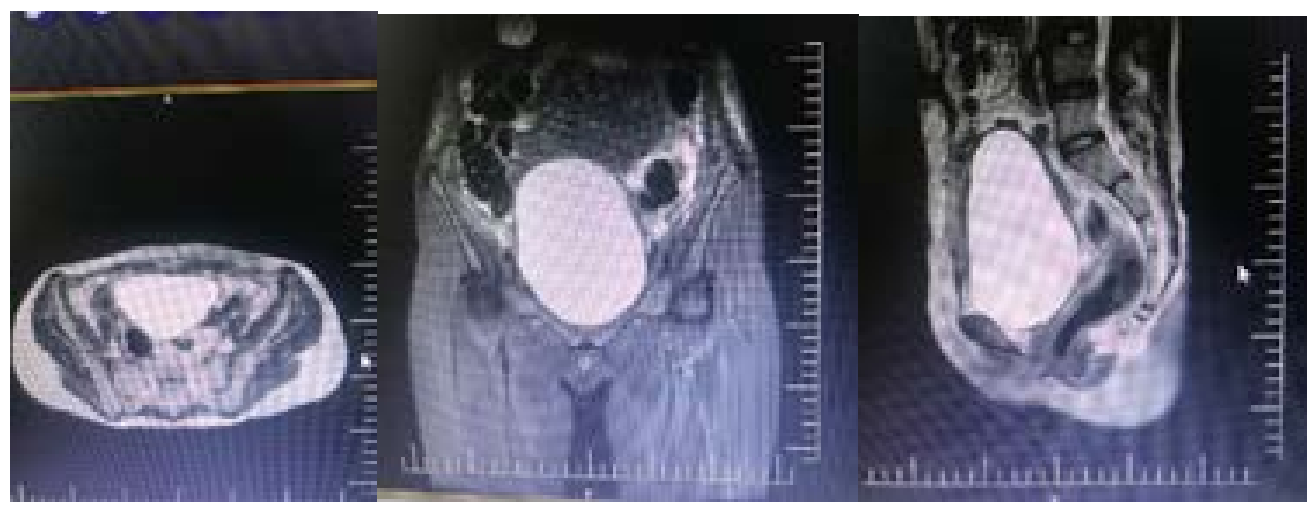

Resim 6. Hastanın radyolojik görüntüleri. çökük, ortopne (+), sağ hemitorakstan solunum sesleri alınmıyor, batın distandü ve yaygın asit mevcut olup, sağ alt kadranda ele gelen sert kitle saptandı. Hastanın laboratuvar değerlendirmesinde WBC: 9980/mm3, MNS: 8330/mm3, Hb: 11,3 g/dL, Hct: \% 34,1 MCV: 77 fL, Plt: 479000/mm3, ESR: $4 \mathrm{~mm} / \mathrm{h}$, CRP: $7 \mathrm{mg} / \mathrm{L}$, BUN: $23 \mathrm{mg} /$ dl, kreatin: $1,31 \mathrm{mg} / \mathrm{dl}$, ürik asit: 13,7 mg/dl, LDH: 2222 $\mathrm{mg} / \mathrm{dl}$ idi. Hastanın batın USG'de sağ umblikal alanda heterojen hipoekoik kitle izlendi. Peritonitis karsinoma lehine değerlendirildi. Batın BT de batın sağ alt kadranda 110x85 mm boyutlu, mezenterik yerleșimli, düzensiz konturlu, vasküler yapıları sarmış, yumuşak doku dansitesinde kitle ve yaygın asit gözlendi. Periton ve plevral sivi yaymasinda mebzul lenfoblastlar görüldü. Tru-cut biyopsi sonucu CD20 Diffüz (+) ve Kİ67: \% 90 ve üzeri $(+)$ olan hastaya Hodgkin dișı lenfoma (Burkitt Lenfoma) 
tanısı kondu. Hodgkin dıșı lenfoma tedavisi başlandı. Hastanın takibinde değişen biyokimyasal veriler grafik olarak resim 7'de görülmektedir. sonra 11 kür kemoterapi almış. Hasta genel durumu kötü, ateşli, şuur letarjik, sağ bacakda purpura fulminans varlığı ve sağ femurdan batına sağ umblikusa kadar
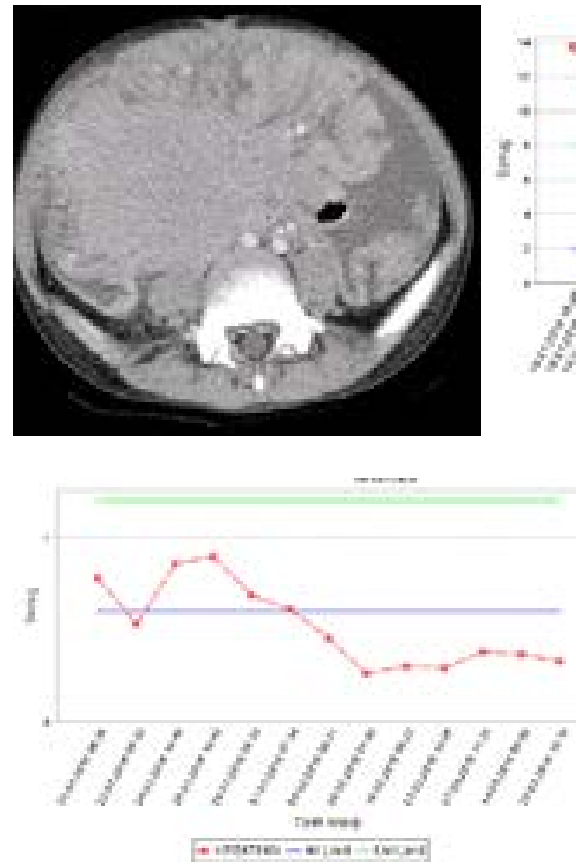

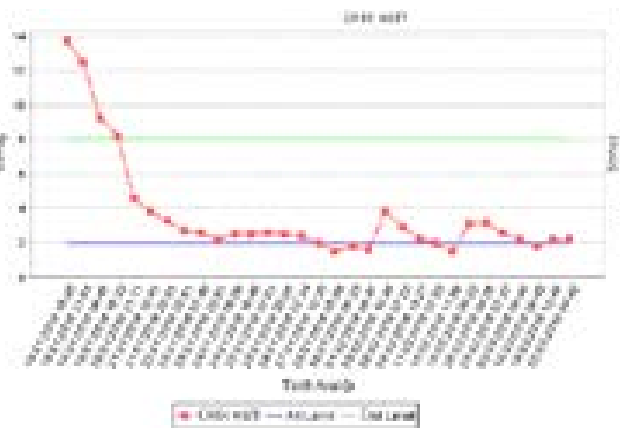

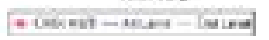

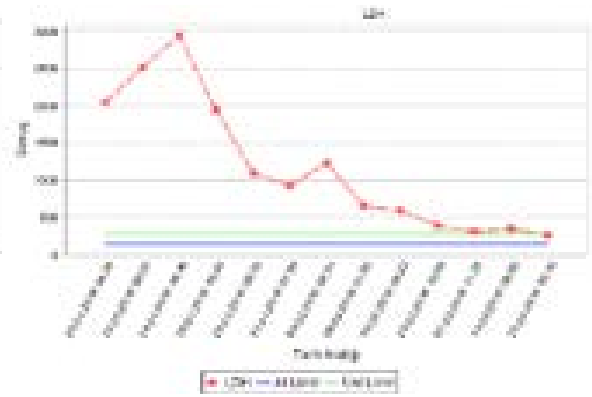

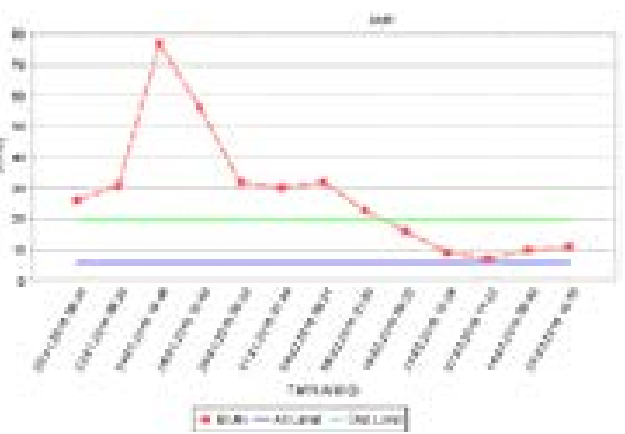

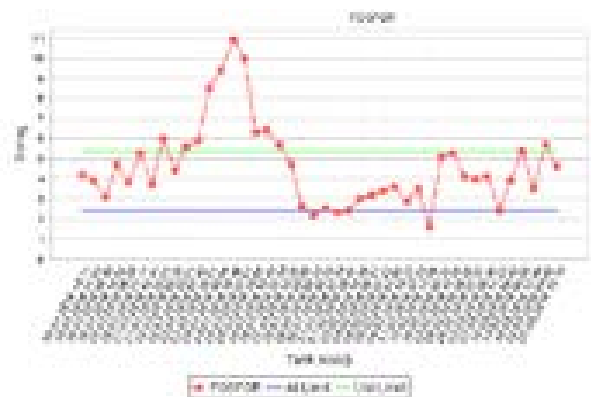

Resim 7. Hastanın sırayla batın tomografi görüntüsü, ürik asit, BUN, kreatinin, LDH ve fosfor değerleri.

OLGU 9. 11 yaşında kız hasta sağ submandibular ve alt çene diş eti, bukkal mukozada kitle ile başvurdu. Hastanın solunum sıkıntısı ve belirgin ortopnesi vardı. Akciğer grafisinde belirgin mediasten genişlemesi saptandı (Resim 8). Laboratuvar tetkiklerinde WBC: 7930/mm3, Hb: 11,5g/dL, Plt: $362000 / \mathrm{mm} 3$ ve biyokimyasal parametreleri normal aralikta bulundu. Hastada malignite düşünüldü (lenfoma?). Hastadan ameliyathane şartlarında lenf adenopati biyopsisi, kemik iliği aspirasyonu ve biyopsisi planlandı. Vena kava süperior sendromu bulguları olan hastaya işlem öncesi steroid düşük doz başlandı. Takibinde hastada satürasyon düşüklüğü oldu ve hasta arrest oldu. Entübe edilemedi ve trakeostomi açılmak zorunda kalındı. Kemik iliği biyopsisinde lenfoma tutulumu saptandı. Lenf adenopati biopsi sonucu, Hodgkin dişı T hücreli lenfoblastik lenfoma tanısı kondu. Hodgkin dışı lenfoma evre IV olarak yorumlanan hastaya kemoterapi başlandı. uzanan dev kitle ile acile başvurdu (Resim 9). Cekilen sağ bacak ve batın MR'da batın sağ alt kadrandan sağ uyluk proksimal segment ve kas planları içerisine uzanım gösteren $\sim 180 \times 100 \times 100$ kitle ve lezyon sağda pelvik kemiklerde ve femur proksimal segmenti çevrelemiş olarak görüldü. Laboratuar tetkiklerinde WBC:1340/ mm3, MNS: 590/mm3, Hb 10,9 g/dl, Hct: \% 30, MVC 85,7 fL, Plt:12000/mm3, CRP 340 mg/L, PT:19,2 sn, INR: 1.71, PTT: 37 saniye olan hastanın kan kültürlerinde sirasiyla E. coli, MRSE, VRE, Achromobacter species üremeleri oldu. Hastaya yüksek riskli febril nötropeni tanısiyla meropenem, teikoplanin ve amikasin tedavisi başland. Trombosit aferezi süspansiyonu ve taze donmuş plazma desteği yapıldı.

\section{TARTIŞMA}

Olgu 1'de sunduğumuz hastada von Willebrand hastalığ 1 mevcuttur. von Willebrand hastalığ vWf veya fonksiyon bozukluklarına bağlı, otozomal geçişli en sık görülen bir kalitsal kanama diyatezidir. vWf azalmış seviyeleri göreceli olarak yaygın olmakla birlikte, hastaların sadece bir kısmı kanama semptomları nedeniyle tıbbi dikkati çeker ve vWh tanisi alır (2). vWh'nın farklı alt tipleri bulunmakla birlikte yapılan bazı çalışmalarda hemartroz, kas hematomu, ağız boşluğu
OLGU 10. Ewing sarkom tanısıyla takipli 4 yaşında erkek Suriyeli misafir hasta daha önce opere olduktan 


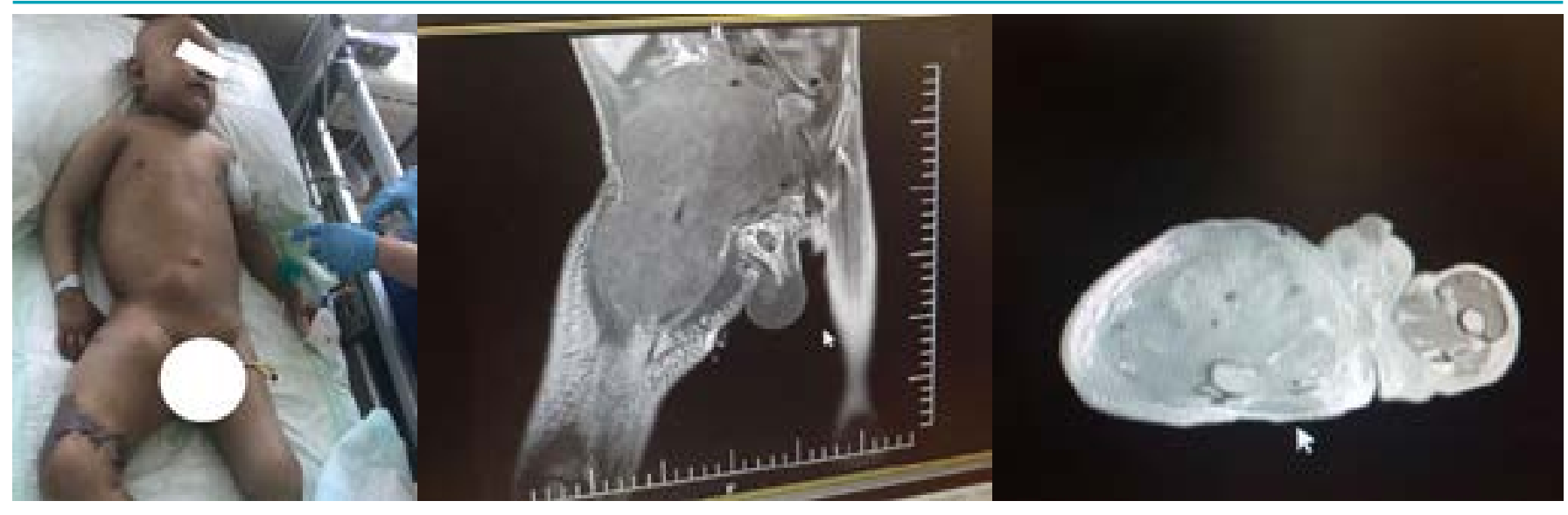

Resim 9. Hastanın görüntüsü ve bacak MR görüntüleri.

kanaması ve epistaksis gibi ağır kanama vakaları Tip 3 vWh'da bildirilmiştir (3). Tip $3 \mathrm{vWh}$, homozigot veya bileşik heterozigot mutasyonlara bağlı olarak vWh, mRNA ekspresyonunun kaybı ile sonuçlanan belirgin bir vWf azalması veya yokluğu ile karakterizedir (4). Hastamızda olduğu gibi vWh'nın ilk başvurusunun hayatı tehdit eden intrakranial kanama ile olabileceği unutulmamalıdır.

Olgu 2'de sunduğumuz hastada da görüldüğü gibi akut immun trombositopeni çocukluk çağında 3 aylıktan itibaren, sıklıkla 2-6 yaş arasında kızlarda ve erkeklerde eşit oranda görülür (5). Hastalar sıklıkla peteşi, purpura ile başvurur. Dişeti kanaması, gastrointestinal kanama ve hematüri daha az sıklıkla görülürken, intrakranial kanama sıklığ $1 \% 0,5$ ile \% 1,5 arasında bildirilmektedir (6). İntrakranial hemoraji ile ilgili belirtiler ve semptomlarla başvuran çocuklar (örneğin, baş ağrısı, kalıcı kusma, değişen mental durum, nöbetler, fokal nörolojik bulgular, son kafa travması) acil değerlendirmeyi (nöro görüntüleme dâhil) ve tedaviyi gerektirir (7). Burada sunulan olgu intrakranial kanama gibi nadir komplikasyonlardan biri ile başvurmuştur.

Glikoz-6-fosfat dehidrojenaz (G6PD) eksikliği, X’e bağlı genetik geçiş gösteren dünyadaki 400 milyondan fazla insanı etkileyen, insanlarda en sık görülen eritrosit bozukluğudur (8). G6PD enzim eksikliğinde oksidan madde ile temas ettikten 2-3 gün sonra intravasküler hemoliz meydana gelmesi sonucu hemoglobinemi, hemoglobinüri ve hematokrit düşüşü olur (9). Anemi, sarllık ve retikülositoz meydana gelir. Bazen derin hemoliz, hemoglobinüri ve akut böbrek yetmezliği gelişebilir (10). G6PD eksikliğinin Akdeniz bölgesi varyantında, fava fasulyesi veya bakla tüketilmesine bağlı akut ve çok şiddetli hemolitik kriz görülmekte ve hatta ölüme neden olmaktadır (11). Olgu 3'de sunduğumuz hastada görüldüğü gibi hasta başvurduğunda hem hemoglobin düşüklüğü, hem de koyu renk idrarı olması ve hemoliz yapabilecek risk faktörüne maruz kalmış olması G6PD eksikliğini düşündürmelidir.

Olgu 4'de sunduğumuz hastada olduğu gibi diğer bir hemolizle seyreden hastalık da otoimmun hemolitik anemidir. Otoimmün hemolitik anemi (OIHA), otolog eritrositlere karşı antikor yapımı ile karakterize bir anemi grubudur. Erkek ve kadında eşit gözlenir. İmmün hemolitik anemide eritrosit membranına antikorların ve/ veya kompleman komponentlerinin bağlanması sonucu eritrosit yıkımı meydana gelir. Bu yıkım otoimmün, alloimmün ya da ilaçlara bağlı immüno-hemolitik anemilerdir. İmmün hemolitik anemilerde \% 95 direkt Coomb's testi pozitiftir (12).

Demir eksikliği normal fizyolojik fonksiyonları korumak için toplam vücut demirinin yetersiz olmasıdır. Demir eksikliği beş yaşına kadar olan çocuklarda serum ferritin $<12$ mikrogram/L veya beș yaş ve üstü bireylerde ferritin $<15$ mikrogram/L ile tanımlanır (13). Olgu 5'de sunduğumuz hastamız demir eksikliği anemisi ile takipli iken batında kitle olduğu tarafımızca fark edilmiştir. Anemi tanısıyla takip edilen hastalar sadece kan tetkikleriyle değil tam sistemik muayene yapılarak takip edilmelidir.

Bölgemizde sık gördüğümüz diğer bir hemolizle seyreden hastalığımız ise olgu 6'da sunduğumuz orak hücre anemisidir. Orak hücre anemisi (OHA), otozomal resesif geçis gösteren, eritrositlerin erken yıkımına neden olan genetik bir hastalıktır. Klinik belirtilerin her biri kan viskozitesinin artımı ile ilgilidir. Kanın viskozitesi, membranın rijiditesi, hemoglobin polimerizasyonu ve hücre içi hemoglobin konsantrasyonunun artması gibi faktörlerle artar. Oraklaşmış hücrenin damar endotelyumuna yapışmasının artması, perfüzyonun sınırlanmasına yol açar. Sonuçta dalak, kemik iliği ve plasentada çoğul odakçıllar halinde infarktüsler ve fibrosis görülür (14). Hastalar genellikle erken yaşlarda tanı alırken olgu 6'da sunduğumuz hastamız ileri dönem komplikasyonlardan otosplenektomi oluştuktan sonra tanı almıştır. Bu nedenle kan parametreleri benzer olan hastaların bu şekilde tanı alamamıs OHA hastaları olabileceği unutulmamalıdır.

Anormal uterin kanama (AUB), normal siklik menstrüasyonun dıșında süre veya miktar olarak fazla olan uterin kanamayı gösterir (15). Ağır adet kanaması olan ergenlerde, $\mathrm{vWh}$, immüntrombositopeni, trombosit disfonksiyonu ve maligniteye sekonder trombositopeni veya malignite tedavisi (kemoterapi vb) yer alır (16). Olgu 7'de sunduğumuz hastamızın aşırı uterin kanama sebebi malignite olarak bulundu.

Tümör Lizis Sendromu (TLS), hemato-onkolojik acil durumlardan birisi olup kemoterapi (KT) sonrası, bazen de spontan gelişmektedir (17). Çoğunlukla hiperürisemi, hiperkalemi, hiperfosfatemi, hipokalsemi 
ve akut böbrek yetersizliği (ABY) gibi klinik ve laboratuvar bozukluklarla karekterizedir (18). Olgu 8'de sunduğumuz vakamızda tanı öncesinde TLS gelişmiş ve hasta bu bulgular sonrasında tanı alarak tedavi başlamıştır.

Vena kava süperior (SVK) sendromu, SVK'daki kan akımının obstrüksiyonu sonucunda gelişmektedir. SVK sendromu olan hastaların yaklaşık \% 95'inde akciğer kanseri veya non-Hodgkin lenfoma bulunmaktadır. Nefes darlığı, yüzde ödem ve eritem, boyun ve kollarda ödem, boyun ve torasik venlerde dilatasyon başlıca semptom ve bulgularıdır (19). Olgu 9'da sunduğumuz vakamızda SVK sendromunun tüm bulguları bulunmakla birlikte SVK sendromuna bağlı hayatı tehdit eden nefes darlığı sonrası trakeostomi açılması klinik önemini ve hastanın erken tanınması açısından önemlidir.

Ateş, özellikle nötropeni dönemlerinde yaşamı tehdit eden bir enfeksiyonun ilk belirtisi olabilir. Febril ataklar, kemoterapinin neden olduğu nötropeni veya hematopoietik hücre transplantasyonu sonrası çocuklarda nötropenik atakların yaklaşık üçte birinde görülür (20). Geniş spektrumlu bir antipseudomonal beta-laktam (örn. Sefepim veya seftazidim ), bir karbapenem (örn. Meropenem ) veya piperasilintazobaktam ile başlangıç tedavisi, nötropenik hastalarda ateşin komplike olmayan atakları için önerilmektedir (21). Olgu 10'sunduğumuz hastamız kemoterapi sonrası gelişen nötropenik ateş ile başvurarak tedavi başlanmıştır.

Sonuç olarak, hematolojik ve onkolojik acil durumlar, hızlı müdahale gerektiren, ölüm veya kalıcı hasarla sonuçlanabilen akut durumlardandır. Bu nedenle bu grup hastaların ayrıntılı anamnez, fizik muayene ve laboratuvar testleri ile değerlendirilerek, en kısa sürede tanıları konulmalı ve tedavileri başlanmalıdır.

\section{KAYNAKLAR}

1. Atalay G, Başaran M. Onkolojik Aciller. Klinik Gelişim 2004; 17: 16-9.

2. Rodeghiero F, Castaman G, Dini E. Epidemiological investigation of the prevalence of von Willebrand's disease. Blood 1987; 69: 454-9.

3. Lak M, Peyvandi F, Mannucci PM. Clinical manifestations and complications of childbirth and replacement therapy in 385 Iranian patients with type 3 von Willebrand disease. Br J Haematol 2000; 39-41: 1236-9.

4. Ngo KY, Glotz VT, Koziol JA, Lynch DC, Gitschier J, Ranieri P, et al. Homozygous and heterozygous deletions of the von Willebrand factor gene in patients and carriers of severe von Willebrand disease. Proc Natl Acad Sci U S A 1988; 85: 2753-7.

5. Mc Clure PD. Thrombocytopenic purpura in children diagnosis and management. Pediatrics 1975; 55: 68-74.

6. Walker RN, Walker W. Idiopathic thrombocytopenia, inital illness and long term follow up. Arch Dis Child 1984; 59: 316-21.

7. Provan D, Stasi R, Newland AC, Blanchette VS, Bolton-Maggs P, Bussel JB, et al. International consensus report on the investigation and management of primary immune thrombocytopenia. Blood 2010; 115: 168-86.

8. Cappellini MD, Fiorelli G. Glucose-6-phosphate dehydrogenase deficiency. Lancet 2008; 371: 64-74.

9. Berkow R. The Merck Manuel G6PD Tanı / Tedavi El Kitabı. çeviri ed: Keklikoğlu M, Tuzcu M. İstanbul: Nobel Tip Kitabevleri Ltd, 1995: 1136-74.

10. Andrews MM, Mooney KH. Alterations in hematologic function in children. In: Mc Cance KL, Huether SE, eds. Pathophysiology. Missouri: Mosby-Year Book Inc., 1994: 908-42.

11. Fairbanks VF, Klee GG. Biochemical aspects of hematology. In: Burtis CA, Ashwood ER, eds. Tietz Textbook of Clinical Chemistry. USA: WB Saunders Co 1994:1974-9.

12. Ayker E, Çınar M, Göközdoğu G, Aksoy Z, Bambul N. Otoimmün hemolitik anemi. Göztepe Tip Dergisi 2001; 16: 108-10.

13. Powers JM, Buchanan GR. Potential for improved screening, diagnosis and treatment for iron deficiency and iron deficiency anemia in young children. J Pediatr 2017; 188: 8-10.

14. Kılınç Y. Orak hücre anemisi: Tanı, takip, tedavi ve transfüzyon. Talasemi ve hemoglobinopatiler 2010: 255-62.

15. ACOG Committee Opinion No. 651: Menstruation in Girls and Adolescents: Using the Menstrual Cycle as a Vital Sign. Obstet Gynecol 2015, 126 (6) :e143-6.

16. Munro MG, Critchley HO, Broder MS, Fraser IS; FIGO Working Group on Menstrual Disorders. FIGO classification system (PALM-COEIN) for causes of abnormal uterine bleeding in nongravid women of reproductive age. Int J Gynaecol Obstet 2011; 113: 3-13.

17. Pi J, Kang Y, Smith M, Earl M, Norigian Z, McBride A. A review in the treatment of oncologic emergencies. J Oncol Pharm Pract 2016; 22: 625-38.

18. King JE. What is tumor lysis syndrome? Nursing 2008; 38: 18.

19. Yilmaz M. Vena Kava Superior Sendromu. Turkiye Klinikleri J Hematol-Special Topics 2016; 9: 21-5.

20. Castagnola E, Fontana V, Caviglia I, Caruso S, Faraci M, Fioredda F, et al. A prospective study on the epidemiology of febrile episodes during chemotherapy-induced neutropenia in children with cancer or after hemopoietic stem cell transplantation. Clin Infect Dis 2007; 45: 1296-304.

21. Freifeld AG, Bow EJ, Sepkowitz KA, Boeckh MJ, Ito JI, Mullen CA, et al. Infectious Diseases Society of America.Clinical practice guideline for the use of antimicrobial agents in neutropenic patients with cancer: 2010 update by the infectious diseases society of america. Clin Infect Dis 2011; 52: e56-93. 